\title{
A Multidimensional Comparative Analysis of Involvement in CSR Activities of Energy Companies in the Context of Sustainable Development Challenges: Evidence from Poland
}

\author{
Tomasz L. Nawrocki * and Danuta Szwajca
}

check for

updates

Citation: Nawrocki, T.L.; Szwajca, D. A Multidimensional Comparative Analysis of Involvement in CSR Activities of Energy Companies in the Context of Sustainable Development Challenges: Evidence from Poland. Energies 2021, 14, 4592. https:// doi.org/10.3390/en14154592

Academic Editors: Sergey Zhironkin and Patrycja Hąbek

Received: 31 May 2021

Accepted: 26 July 2021

Published: 29 July 2021

Publisher's Note: MDPI stays neutral with regard to jurisdictional claims in published maps and institutional affiliations.

Copyright: (c) 2021 by the authors. Licensee MDPI, Basel, Switzerland. This article is an open access article distributed under the terms and conditions of the Creative Commons Attribution (CC BY) license (https:// creativecommons.org/licenses/by/ $4.0 /)$.
Department of Economics and Informatics, Faculty of Organization and Management, Silesian University of Technology, Roosevelta 26-28, 41-800 Zabrze, Poland; danuta.szwajca@polsl.pl

* Correspondence: tomasz.nawrocki@polsl.pl

Abstract: In recent years, corporate involvement in CSR has become increasingly important and appreciated in the context of the ideas and assumptions regarding sustainable development. Due to the specificity of the energy sector, its particular impact on the environment, the living conditions of the population, and the social involvement of energy companies is particularly desirable, therefore it is observed and assessed by many stakeholder groups. The aim of this article is to assess the CSR commitment of Polish energy companies listed on the Warsaw Stock Exchange. The assessment was based on the proposed indicator model, based on the data published in the annual reports of the companies. The study uses data from the years 2016-2020. The main research question is as follows: What is the engagement in CSR activities of six Polish energy companies towards contractors, investors, employees, society, and the environment? The obtained results show that the investigated energy companies present a similar average level of engagement in CSR activities. The highest level of involvement concerns the area of contractors and the lowest levels relate to the donors of capital and the environment.

Keywords: corporate social responsibility; energy companies; sustainable development

\section{Introduction}

The CSR concept has been of interest to scientists and researchers in numerous fields for many years. It is also implemented to a greater or lesser extent in enterprises. Over the past two decades, the meaning and approach of CSR has changed significantly as a result of increased awareness and interest from the public, media, international organisations, regulators, and governments [1]. This new approach to CSR has a much broader context. It concerns the relationship and linkages between business and society in many dimensions: economic, political, ethical-legal, cultural, or ecological and is linked to the concept of sustainable development [2-6]. Companies, in their quest to generate profit, must respect not only legal regulations but also ethical principles, environmental impacts, requirements and expectations of many stakeholder groups, and assumptions on sustainable development formulated by state authorities and international institutions [7].

CSR encompasses a wide range of activities concerning the enterprise's approach to the natural environment, its relations with various stakeholder groups, and its approach to compliance with the law and ethical principles. One of the fundamental aspects of CSR is environmental protection. Pro-environmental activities of enterprises are to constitute a kind of compensation for technical and technological development that, on the one hand, generates measurable economic benefits and, on the other hand, leads to degradation of the natural environment. The energy sector is particularly important and specific in this aspect.

The aim of this article is to assess the CSR activities of energy companies listed on the Warsaw Stock Exchange in the context of sustainable development challenges using an indicator model based on data published in their annual reports. The need to assess 
CSR activities in the power industry results from the fact that this industry has a particular impact on the natural environment and living conditions of the inhabitants. Although companies are in most cases not legally obliged to CSR activities or to report them, they do both, guided by different motives including succumbing to pressure from different stakeholder groups [8,9]. In addition to assessing the involvement of energy companies in CSR, the aim of our study is to identify gaps and weaknesses in the CSR reporting system of listed companies. In particular, the following research questions were undertaken:

1. What is the importance of CSR in the energy industry in the context of sustainable development challenges?

2. What factors motivating energy companies to engage in CSR have so far been identified by various researchers?

3. What are the problems of assessing companies' engagement in CSR on the basis of information contained in reports?

4. What is the CSR commitment of Polish energy companies listed on the Warsaw Stock Exchange in general and broken down into individual dimensions/aspects?

The research problems formulated have been subordinated to the structure of this article that consists of the following sections. Section 2 presents the meaning and motives of energy companies' involvement in CSR and an overview of methods for assessing this involvement. Section 3 shows the research methodology. Section 4 presents the results obtained. Section 5 is the discussion. Section 6 provides a summary and discusses the implications and limitations of the conducted research.

\section{Literature Review}

\subsection{The Importance of CSR in the Energy Industry}

The energy sector is, on the one hand, essential for the functioning of the economy and daily human existence, providing access to energy, water, and gas, and on the other hand, is one of the main sources of environmental degradation, generating soil, water, and air pollution. Although the share of renewable sources in electricity production is increasing every year [10], conventional sources still dominate in this area. More than $70 \%$ of the world's electricity demand derives from a generation based on coal, oil, and natural gas use. The use of these raw materials negatively affects the environment both at the stage of extraction (soil degradation, groundwater contamination, rock mass movements, shocks, etc.) and at the stage of their processing (carbon dioxide emissions). Nuclear power plants run the risk of contaminating the environment with radioactive substances.

The literature points to three aspects of energy sector responsibility [11]:

- $\quad$ social responsibility (personnel's welfare, skills, and motivation; open interaction with stakeholders; the quality of energy supply; good practice of business and cooperation with the stakeholders, networking with other companies; and correct price for energy);

- environmental responsibility (measurement of environmental impact; awareness and reduction of environmental impacts of energy production and transfer; minimisation of use of fossil fuels; reduction of pollution and emissions; renewable sources development; and control systems for waste and pollution); and

- economic responsibility (cost-effective operations; fair prices and good service; investing in new technologies; reliability of energy supply; and financial risk management).

For these reasons, the activities conducted by energy companies are particularly important for sustainable development. The energy sector is of strategic importance for any economy and also in international relations. Therefore, it is subject to the influence of the state and international organisations. Lu et al. [12] see here the risk of corruption as a major threat to sustainable energy development. They see in the implementation of CSR (especially corporate governance and transparency) with the support of appropriate government policies (anti-corruption standards) a way to reduce this risk.

The energy sector is therefore seen not only as particularly responsible for problems such as climate change, resource scarcity, and environmental pollution $[13,14]$ but also as a 
strategic sector of the economy, determining its sustainable development. Therefore, the energy industry is particularly obliged to apply CSR activities. Social and environmental organisations, public institutions, governments, and citizens expect energy companies to meet higher CSR standards than companies in other industries. This means that CSR for energy companies is not a matter of good will but is actually a requirement and an obligation [11].

An additional important aspect of CSR in the energy industry is the context of supporting developing countries. This is especially true for multinational companies operating in developing countries that are rich in energy resources (e.g., in the oil sector). Using the example of the Luanda Oil refinery in Angola, García Rodríguez et al. [15] point to the significant potential of CSR activities to improve the social and environmental situation of developing countries.

\subsection{Motives of Energy Companies' Involvement in CSR}

Companies engaging in CSR activities are guided by different motives which can be divided into three groups [16]:

- $\quad$ ethical and altruistic motives;

- the desire to obtain various benefits including financial ones; and

- $\quad$ to respond to social expectations and stakeholder pressure.

As far as ethical and altruistic motives are concerned, they are rarely the sole, standalone argument for companies' engagement in CSR. In practice, these motives are linked to the others [17-19].

Very often, companies undertaking CSR initiatives expect to obtain specific benefits including financial ones. Numerous studies conducted to date have not clearly shown a positive relationship between the level of CSR engagement and financial performance [20-28]. This is also true for the energy industry. Pätäri et al. [29] analysed the interrelationship between CSR investments and financial performance in the energy sector using data from 1991 to 2009. The results did not confirm bidirectional causality between CSR and financial performance but rather showed only some long-term effects of CSR on profitability and market value of the companies studied. A study conducted in the global energy sector using data from 2011 to 2018 showed that higher CSR spending does not ensure better financial performance of energy companies [30].

Although research over the years has not conclusively confirmed the positive impact of CSR on corporate financial performance, numerous studies have shown that engagement in CSR generates a variety of positive effects such as:

- building a positive reputation and image, increasing brand value, and improving customer loyalty and purchase intentions [31-35];

- $\quad$ risk reduction and cost of capital [36-38];

- $\quad$ buffering effect during crisis, e.g., product-harm crisis [39-41]; and

- tax benefits, free publicity, and attractiveness as an employer [42-44].

An important stimulus for the application of CSR is the need to respond to social expectations and stakeholder pressure in order not only to gain their favour and support $[9,45,46]$ but to obtain a kind of social license (legitimacy) for their activities. Obtaining such a license is a serious challenge especially for the mining [47] and energy industry [48]. A particular form of stakeholder pressure is associated with the operation of sustainable supply chains of which energy companies are participants [49]. An important factor motivating energy companies to apply CSR principles are regulations at the international and national level (government policies). For example, China has been introducing CSR regulations as of 2006 as part of a specific sustainable development policy called the social harmony policy. These regulations mainly refer to the mining industry on which the Chinese energy industry is based [50]. In contrast, researchers from the Baltic countries suggest that sustainability in the energy sector can be effectively implemented without 
state intervention but through voluntary implementation of CSR by energy companies based on effective public-private partnerships [51].

Latapí Agudelo et al. [52], based on a systematic review of literature from 1990 to 2018 on CSR in the energy industry, identified factors that motivate energy companies to implement CSR. Among them, they distinguished four external factors, five external factors, and three connecting factors (Figure 1).

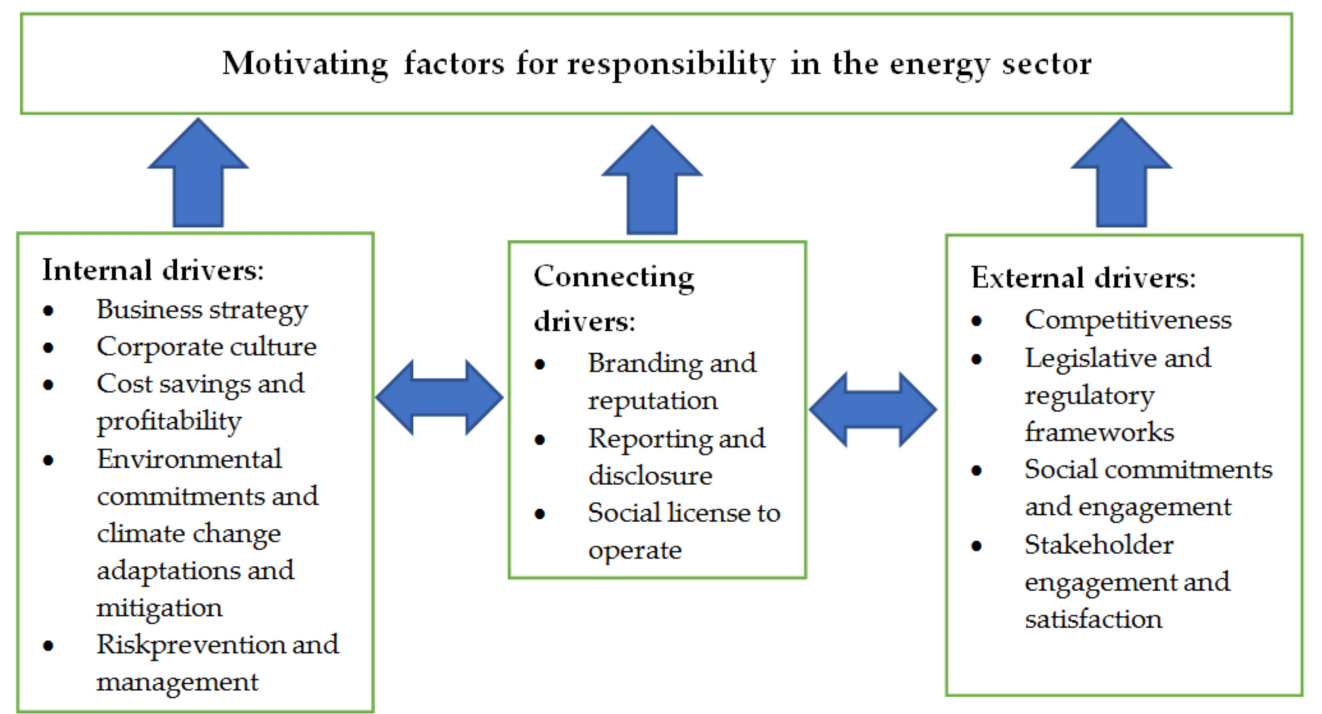

Figure 1. Motivating factors for CSR in the energy sector. Source: own work based on [52].

External factors relate to the increasing competition in the industry related to the possibility of using different alternative energy sources, the growing number of national and international regulations with regard to the energy sector in the context of climate change, the interest and pressure from society represented by various national and international organisations and institutions, as well as other stakeholder groups. Internal factors are related to building an organisational culture and corporate strategy based on CSR, the desire to reduce costs and increase company profitability, and the need to adapt to climate change and reduce its pace and scope. Latapí Agudelo, Johannsdottir, and Davidsdottir [52] suggest that many companies in the energy sector are seeking to use CSR to build their risk management strategies and be proactive in the context of ongoing climate change. The connecting factors are efforts to build a positive reputation and image as a socially responsible company through reporting and transparency of CSR activities in order to gain social legitimacy and stakeholder support for their business operations.

Many authors suggest that CSR should be permanently embedded in a company's strategy and should even be applied as a business strategy $[53,54]$. They claim that only in this way can it provide long-term benefits in the form of a positive reputation and strong brand which will consequently translate into better financial performance and long-term competitive advantage. In order for the effects of CSR to be as good as possible, it is recommended to implement initiatives that are well integrated into the core business of the company [55], as well as to disclose and publish information about CSR engagement in reports and statements, respecting the principles of transparency [56,57].

\subsection{Dilemmas in Assessing Companies' Involvement in CSR}

The need to assess and measure CSR is triggered, on the one hand, by the necessity and desire to inform various stakeholder groups about the company's social involvement in order to build a positive image and enhance reputation, which requires the inclusion of specific data in reports and statements [58]. On the other hand, the need for measurement stems from the fact that companies, guided primarily by economic criteria, want to assess the effectiveness of CSR activities undertaken, which requires their recording and 
recognition in terms of costs and revenues $[59,60]$. In principle, the need to assess and measure CSR is not questioned; however, an important problem is to identify appropriate procedures and instruments for this measurement [61-66]. Many methods and tools have been developed so far such as:

- $\quad$ socially responsible company indices, reputation indices, and social rankings [62-64];

- certification and accreditation, refering to the use of international standards: SA 8000, ISO26000, and ISO14001 [58];

- $\quad$ analysis of CSR content included in annual reports, financial statements (according to GRI guidelines or AccountAbility1000Standard), and websites; and

- $\quad$ measuring the attitudes and value system of individuals using a rating scale [67].

Although many concepts and solutions have been developed, up to date no uniform, widely accepted methods and tools have been developed in this field [57,68,69]. Among other aspects, the difficulties of assessment stem from the multidimensionality of CSR and the qualitative nature of many of its activities [70].

The assessment of CSR on the basis of the content analysis of reports is hampered by two main issues. First, as the disclosure of CSR information in many countries including Poland is not obligatory (companies are not legally bound to do so), not all companies disclose this information. Among European countries, only countries such as Sweden, France, Great Britain, and Denmark have introduced an obligation to report selected CSR issues. In turn, the Global Reporting Initiative (GRI) guidelines are most frequently used in Sweden, Italy, Spain, Denmark, France, and the Netherlands, and least frequently in the Czech Republic, Poland, Germany, and the UK [71]. Secondly, the information disclosed in the reports is not standardised; it has a very diverse content, scope, and form. The information is often too general or fragmentary and the form is descriptive without quantitative or indicative terms, which resulting in comparisons over time and between companies to be impossible [56]. A change towards harmonisation of CSR reporting standards not only at the national but also at the international level would be necessary in this respect [72,73]

\section{Materials and Methods}

For the purposes of the proposed method of assessing companies' involvement in socially responsible activity, the perspective of the six following stakeholders was adopted, i.e.,: business partners (suppliers/customers), employees, society, donors of capital/investors, the environment, and specific assessment criteria were assumed to be based on publicly available data published by companies in their periodical (mainly annual) reports. It should be noted that the adopted assumptions, on the one hand, make the final assessments comprehensive and, on the other hand, enable easy generation and updating of these assessments (writing down a dozen or so data from periodic reports of companies is certainly incomparably less labour and time-consuming than preparing and conducting subsequent surveys).

Bringing together the key issues postulated in the literature in the context of evaluating companies' behaviour towards particular stakeholder groups [74-76] and the information value (information capacity) of periodic reports published by companies, Table 1 lists the proposed partial evaluation criteria within particular thematic areas. The proposed criteria also considers the specifics of the companies' activities in the energy sector.

The final synthetic assessment of a given entity's involvement in a socially responsible activity in the proposed solution is assumed to be obtained as a result of the implementation of subsequent steps according to the scheme presented in Figure 2. Proposed procedure is typical for solutions based on multidimensional comparative analysis methods [77-80]. 
Table 1. Evaluation criteria for the different thematic areas of corporate social responsibility in the energy sector.

\begin{tabular}{|c|c|c|}
\hline Criterion Symbol & Criterion Name/Thematic Area & Criterion Nature * \\
\hline \multicolumn{3}{|c|}{$\begin{array}{l}\text { Area of counterparties } \\
\text { (suppliers/customers) }\end{array}$} \\
\hline$x_{1}$ & $\begin{array}{c}\text { Repayment period of liabilities: average } \\
\text { trade liabilities } \times 365 \text { days / sales } \\
\text { revenues }\end{array}$ & $\mathrm{D}$ \\
\hline$x_{2}$ & $\begin{array}{l}\text { Receivables collection cycle: average } \\
\text { receivables } \times 365 \text { days/sales revenue }\end{array}$ & $S$ \\
\hline$x_{3}$ & $\begin{array}{l}\text { Ratio of reserves for lawsuits and } \\
\text { compensations to equity }\end{array}$ & $\mathrm{D}$ \\
\hline$x_{4}$ & $\begin{array}{l}\text { Ratio of compensations, penalties, and } \\
\text { fines paid and received to sales revenue } \\
\text { Area of capital donors } \\
\text { (investors/creditors) }\end{array}$ & $\mathrm{D}$ \\
\hline$x_{5}$ & $\begin{array}{l}\text { Return on equity: } 12 \text {-month net } \\
\text { result/average equity }\end{array}$ & $S$ \\
\hline$x_{6}$ & $\begin{array}{l}\text { Dividend yield: dividend per } \\
\text { share/market price of share }\end{array}$ & $\mathrm{S}$ \\
\hline$x_{7}$ & $\begin{array}{c}\text { Ratio of net debt to net result on sales } \\
\text { plus depreciation and amortisation } \\
\text { Area of employees }\end{array}$ & $\mathrm{D}$ \\
\hline$x_{8}$ & Salaries and benefits per employee & $\mathrm{S}$ \\
\hline$x_{9}$ & $\begin{array}{l}\text { Ratio of salaries and employee benefits to } \\
\text { sales revenue }\end{array}$ & S \\
\hline$x_{10}$ & $\begin{array}{l}\text { Ratio of salaries and employee benefits to } \\
\text { costs of external services }\end{array}$ & $S$ \\
\hline$x_{11}$ & $\begin{array}{c}\text { Percentage change in employment } \\
\text { Area of society }\end{array}$ & $S$ \\
\hline$x_{12}$ & Relation of donations to sales revenue & $S$ \\
\hline$x_{13}$ & $\begin{array}{l}\text { Effective tax rate: income tax paid/gross } \\
\text { financial result }\end{array}$ & $S$ \\
\hline$x_{14}$ & $\begin{array}{c}\text { Ratio of charges due to taxes (other than } \\
\text { income taxes) and fees to sales revenue } \\
\text { Area of environment }\end{array}$ & S \\
\hline$x_{15}$ & $\begin{array}{l}\text { Ratio of energy and materials } \\
\text { consumption costs to sales revenues }\end{array}$ & $\mathrm{D}$ \\
\hline$x_{16}$ & $\begin{array}{l}\text { Share of installed renewable energy } \\
\text { capacity in total installed capacity }\end{array}$ & $S$ \\
\hline$x_{17}$ & $\begin{array}{l}\mathrm{CO}_{2} \text { emissions per unit of } \\
\text { energy produced }\end{array}$ & $\mathrm{D}$ \\
\hline$x_{18}$ & $\begin{array}{c}\text { Share of renewable energy sources in } \\
\text { total energy production }\end{array}$ & $S$ \\
\hline
\end{tabular}
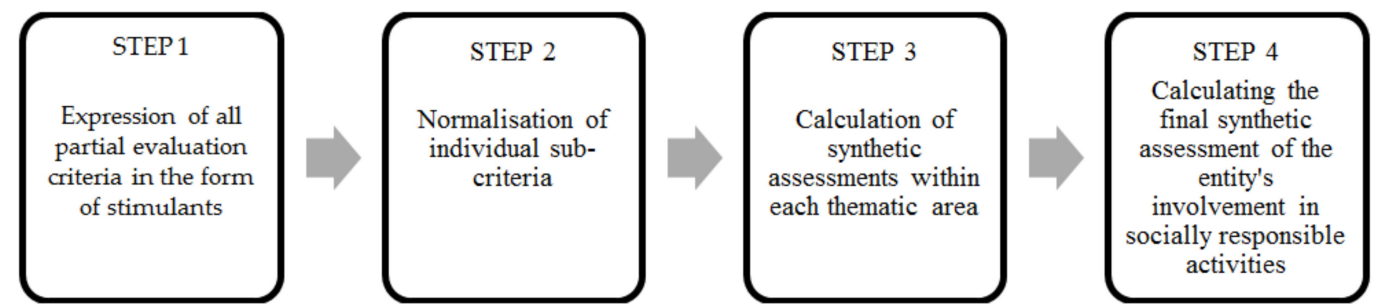

Figure 2. Diagram of the process for obtaining a synthetic evaluation of a company's involvement in socially responsible activities.

First, for the purpose of normalisation, it is necessary to express all the partial evaluation criteria as stimulants. From the perspective of the criteria distinguished in Table 1 , 
such an operation should be conducted for several of them that are destimulants, according to the formula:

$$
x_{j}=c_{j}-x_{j}^{D}
$$

where:

$x_{j}^{D}$ is a destimulant variable,

$x_{j}$ is a variable brought into the stimulant form,

and $c_{j}$ is a positive constant (its value dependant on the value of the variable concerned).

As the sub-criteria identified within the thematic areas differ in units of measurement and ranges of numerical values, they should be normalised for the purpose of their unification. This normalisation will simplify the calculation of synthetic measures within individual subject areas, as well as the calculation of the overall assessment of a company's involvement in socially responsible activity. In this context, it was decided to use the min-max method:

$$
z_{t j}=\frac{x_{t j}-\min \left(x_{j}\right)}{\max \left(x_{j}\right)-\min \left(x_{j}\right)},
$$

where

$x_{t j}$ is the value of the $j$-th assessment criterion in the $t$-th test period

and $z_{t j}$ is the normalised value of the $j$-th assessment criterion in the $t$-th test period (from 0 to 1 ).

In order to avoid distortions caused by abnormal (too high or too low) readings of the values of individual sub-criteria, it was decided to arbitrarily determine their highest (max) and lowest ( $\mathrm{min}$ ) reference levels based on the distribution of their values in the research sample or a common interpretation. Simultaneously, if as a result of the above assumptions a situation arises that $x_{t j}>\max \left(x_{j}\right)$ for the calculation, $\max \left(x_{j}\right)$ is taken as $x_{t j}$.

Finally, the formula of the arithmetic mean of normalised sub-measures $z_{t j}$ (normalised version of the method) was adopted as the basis for the calculation of synthetic measures in individual thematic areas and then, on their basis, for the final assessment of companies' involvement in socially responsible activities according to the methodology of D. Strahl [81]:

$$
M S_{t}=\frac{1}{K} \sum_{j=1}^{K} z_{t j}
$$

where

$M S_{t}$ is the synthetic measure for the assessment of a company's involvement in socially responsible activities in the $t$-th research periods.

The indicated construction of the synthetic measure assumes an equal weight of particular evaluation criteria and a range of accepted values from 0 to 1 . Values closer to 0 indicate a lack of or low involvement of the company in socially responsible activities and values closer to 1 indicate high involvement.

\section{Results}

The practical application of the proposed method for assessing companies' involvement in socially responsible activities was conducted on the example of six energy capital groups listed on the Warsaw Stock Exchange that published their annual reports for 2020 as of the calculation date: Enea, Energa, Polenergia, PGE, Tauron PE, and ZE PAK. All these capital groups meet the EU criteria for large companies, i.e., assets of more than EUR 43 million and annual sales revenues of more than EUR 50 million [82]. The calculations were based on the consolidated annual reports published by the listed capital groups in 2016-2020.

Following the diagram presented in Figure 2, firstly, the relevant data was collected and then, on their basis, sub-criteria were calculated for each thematic area for the period of 2016-2020. The variables obtained were unified to stimulants Formula (1) and normalised 
Formula (2). Next, the cumulative assessments for each thematic area were calculated and, on their basis, the final assessment of the investigated companies' involvement in socially responsible activities Formula (3). The values of $c_{j}, \max \left(x_{j}\right)$, and $\min \left(x_{j}\right)$ needed to convert the variables from destimulants to stimulants and normalise them are presented in Table 2.

Table 2. The values $c_{j}, \max \left(x_{j}\right)$, and $\min \left(x_{j}\right)$ adopted for the individual variables for the purpose of converting them from destimulants to stimulants and normalising the values.

\begin{tabular}{cccc}
\hline Criterion Symbol & Criterion Nature & $c_{j}=\max \left(x_{j}\right)$ & $\min \left(x_{j}\right)$ \\
\hline$x_{1}$ & $\mathrm{D}$ & 150 & 0 \\
$x_{2}$ & $\mathrm{~S}$ & 45 & 0 \\
$x_{3}$ & $\mathrm{D}$ & 0.150 & 0 \\
$x_{4}$ & $\mathrm{D}$ & 0.010 & 0 \\
$x_{5}$ & $\mathrm{~S}$ & 0.150 & 0 \\
$x_{6}$ & $\mathrm{~S}$ & 0.050 & 0 \\
$x_{7}$ & $\mathrm{D}$ & 8 & 0 \\
$x_{8}$ & $\mathrm{~S}$ & 150 & 0 \\
$x_{9}$ & $\mathrm{~S}$ & 0.140 & 0 \\
$x_{10}$ & $\mathrm{~S}$ & 2 & 0 \\
$x_{11}$ & $\mathrm{~S}$ & 0.100 & -0.100 \\
$x_{12}$ & $\mathrm{~S}$ & 0.001 & 0 \\
$x_{13}$ & $\mathrm{~S}$ & 0.190 & 0 \\
$x_{14}$ & $\mathrm{~S}$ & 0.060 & 0 \\
$x_{15}$ & $\mathrm{D}$ & 0.700 & 0 \\
$x_{16}$ & $\mathrm{~S}$ & 1 & 0 \\
$x_{17}$ & $\mathrm{D}$ & 1 & 0 \\
$x_{18}$ & $\mathrm{~S}$ & 1 & 0 \\
\hline
\end{tabular}

After calculations (in accordance with the procedure presented in Figure 2), an overall assessment of the involvement of the investigated energy companies in CSR was obtained, as well as normalized partial and synthetic assessments within each thematic area. The obtained results are presented in Figures 3-8.

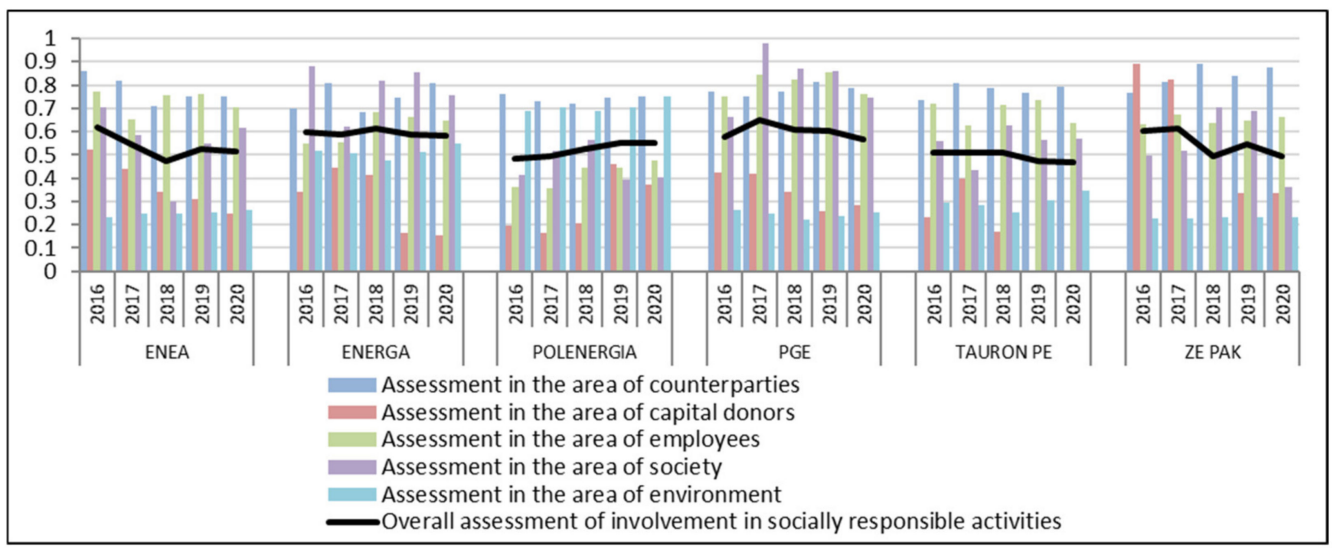

Figure 3. Overall assessment of the investigated companies' involvement in socially responsible activities. 


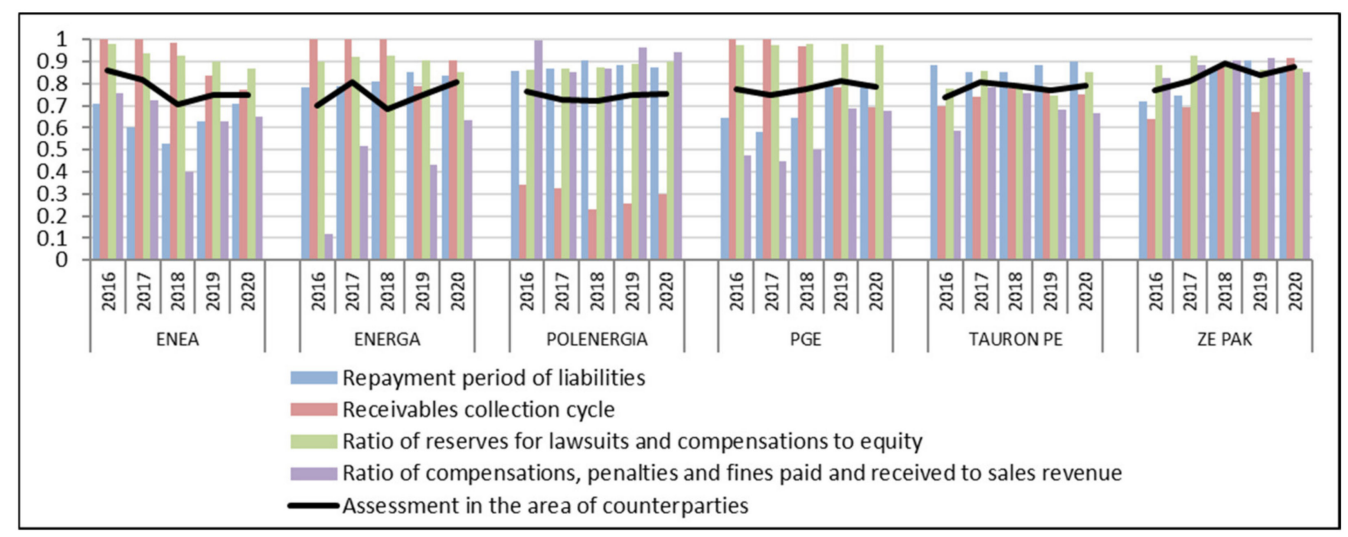

Figure 4. Assessment of the investigated companies' activities in the area of counterparties.

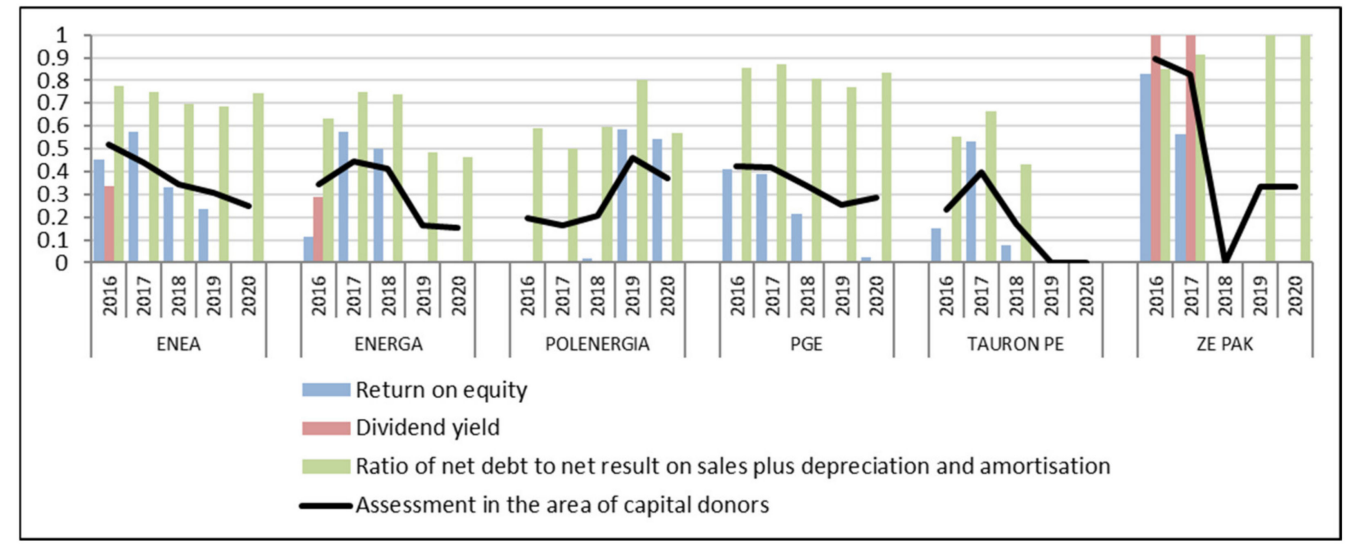

Figure 5. Assessment of the investigated companies' activities in the area of capital donors.

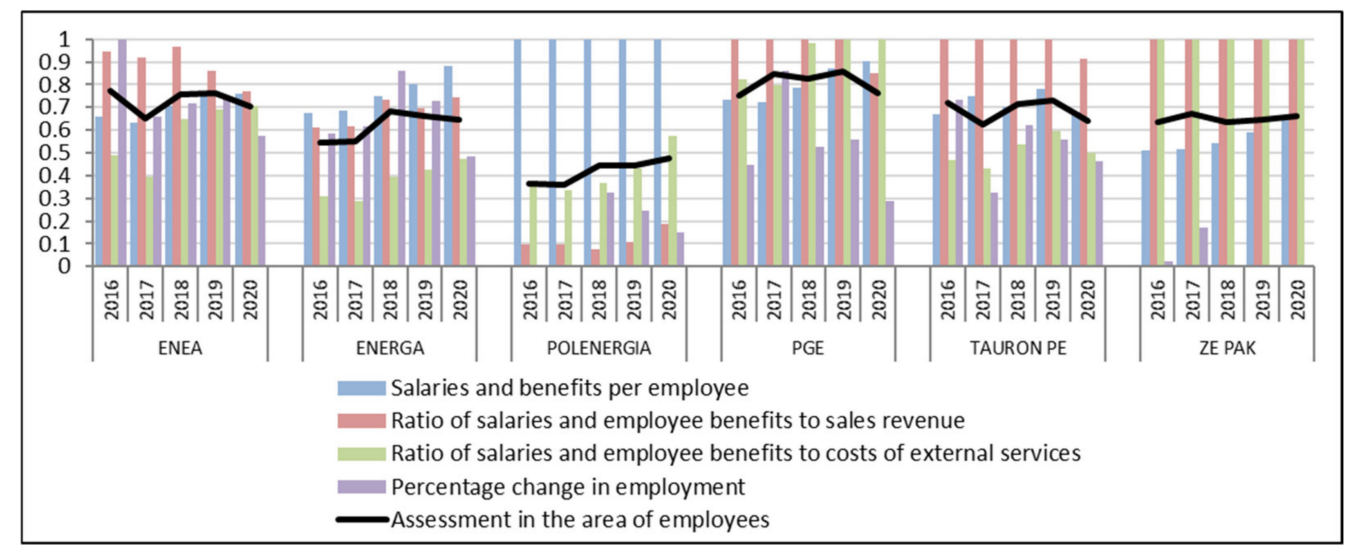

Figure 6. Assessment of the investigated companies' activities in the area of employees. 


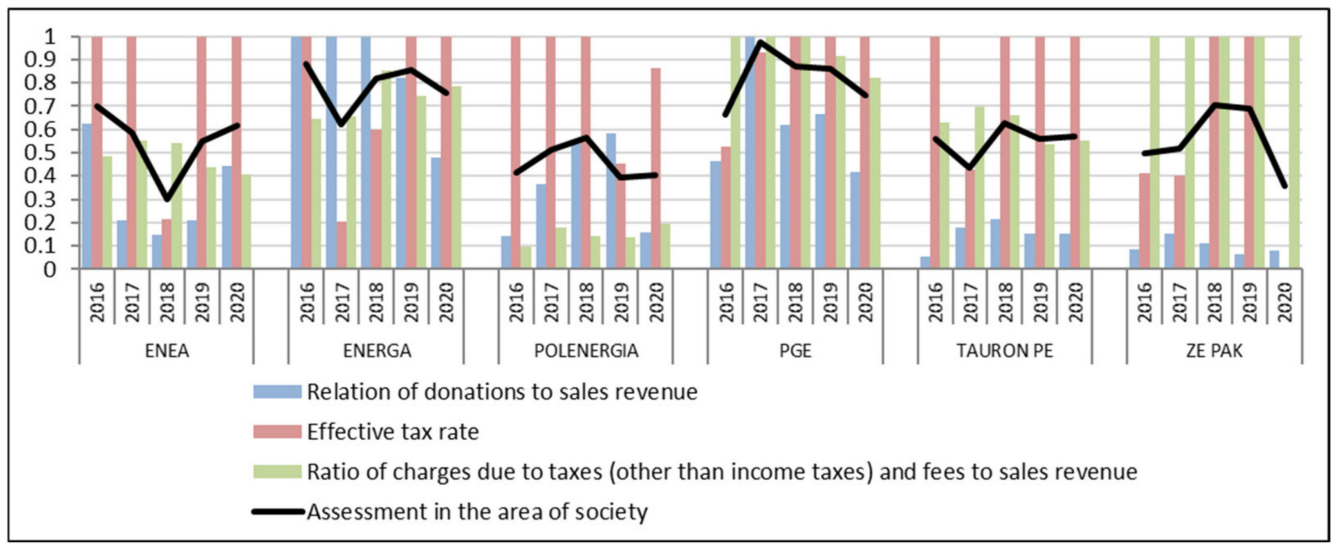

Figure 7. Assessment of the investigated companies' activities in the area of society.

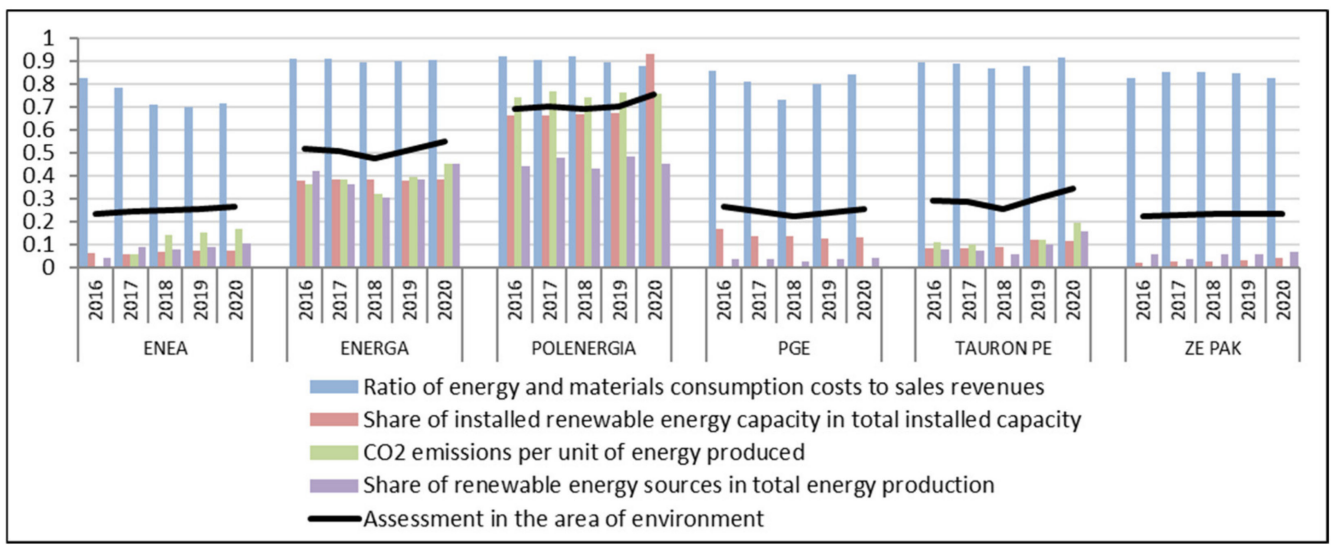

Figure 8. Assessment of the investigated companies' activities in the area of the environment.

As can be observed in Figure 3, the investigated energy companies present a similar overall level of engagement in CSR at the end of 2020 with a score in the range of 0.5-0.6 (only Tauron has a score slightly below 0.5). Conversely, the companies demonstrate quite significant differences in regards to the ratings within particular thematic areas. Simultaneously, some differences between them in the trends of the overall assessment of CSR engagement should be noted. In the case of Polenergia, over the period in question, a systematic improvement can be noted; in the case of Energa, a relative stabilisation; and in relation to the remaining entities, a general worsening of the situation.

In the area of contractors (Figure 4), ZE PAK is the leader with a rating in the range of $0.8-0.9$, while the other power companies with ratings of $0.7-0.8$ are not significantly behind it. ZE PAK's high rating is the effect of equally high and stable ratings for individual sub-criteria in this area over time, while there were some deviations for the other power companies. They mainly concerned the length of the receivables collection cycle and the value of received and paid penalties and fines in relation to sales revenue (this is particularly visible in relation to Energia and Polenergia). The energy companies' exposure to counterparties shows the greatest stability in the period under review with a slight upward trend in almost all companies.

In the area of capital donors (Figure 5), the scores obtained for the investigated energy companies are generally the lowest of all the thematic areas. It should be mainly associated with their poor financial performance in recent years for which the main burden is the costs associated with the energy transition, including the rising price of $\mathrm{CO}_{2}$ emissions rights. On the one hand, this determines it impossible or difficult to share profits with shareholders (lack of dividends) and affects the lower rate of return on equity engaged by them in the investigated entities, and on the other hand, it deteriorates the image of security of debt service in the eyes of creditors. Among the studied energy companies, the 
highest score in the area under consideration at the end of 2020 was obtained for Polenergia but it was only at a level around 0.4 . In the case of the remaining companies, only ZE PAK received a score above 0.3 (mainly due to a significant reduction in financial debt in recent years), while the rest of the studied entities have results below this level (Tauron with a score of 0 is definitely the least favourable). In the period under review, engagement with investors shows the greatest variation with no clear upward or downward trends.

In the area of employees (Figure 6), the most favourable rating is given to PGE with a rating of $0.7-0.8$ at the end of 2020 (and even higher in earlier years). Most other energy companies performed slightly lower with ratings at 0.6-0.7. Only in the case of Polenergia significantly lower results were obtained,- - between 0.3 and 0.5 , albeit with a progressive upward trend. At this point, it is necessary to emphasise the considerable diversity of the investigated entities in terms of partial evaluation criteria in this area that especially concerns the issue of changes in the level of employment and the problem of whether to perform a given activity within the company (employee salary costs) or outsource it (costs of external services). As can be observed in Figure 4, only Polenergia recorded an upward trend in the involvement in the area of employees, while the remaining companies maintain this involvement at a relatively stable or decreasing level.

In the area of society (Figure 7), the investigated energy companies at the end of 2020 are led by Energa and PGE with assessments at the level of 0.7-0.8. Among the remaining entities, they are followed only slightly by Enea with a rating of about 0.6 and Tauron with a rating slightly below 0.6. The weakest are Polenergia (rating of about 0.4) and ZE PAK which recorded a decline from 0.7 to below 0.4 due to the deterioration of the effective tax rate. Considering the sub-criteria of assessment in this area, it can be concluded that the most differentiated situation among the examined energy companies concerned the burden of taxes and fees (excluding income tax) in relation to revenues and donations made. In the period under study, only Enea recorded an increase in its involvement in the area of society. The remaining companies decreased or maintained this involvement at a stable level.

Finally, in the area of environment (Figure 8), the clear leader among the investigated companies is Polenergia with a score of about 0.75 . This company dominates in terms of all the sub-criteria in this thematic area including in particular the commitment to energy production from renewable sources and, what follows, low $\mathrm{CO}_{2}$ emissions. Then, there is Energa with a score of about 0.55 , due to its involvement in renewable energy sources. The results for the other four energy companies are significantly worse at $0.2-0.3$. The situation is particularly poor in PGE and ZE PAK which are the least involved in renewable energy sources and their operations are characterised by high $\mathrm{CO}_{2}$ emissions. A slight upward trend in environmental involvement can be observed in all of the investigated companies with Energa, Polenergia, and Tauron being the most affected.

\section{Discussion}

The discussion is presented in order according to the research questions formulated in the introduction.

\subsection{The Importance of CSR in the Energy Sector}

Due to the enormous impact of the energy sector on the economy, people's living conditions, civilization development, and the state of the environment, we believe that the social responsibility of energy companies is particularly important. Based on the literature analysis $[10,11,13]$, three aspects of responsibility of the energy industry can be identified:

- $\quad$ social and ethical responsibility concerning the quality of the energy supply, cooperation with stakeholders, and interaction with partners in supply chains;

- environmental responsibility concerning primarily the reduction of pollution and $\mathrm{CO}_{2}$ emissions; and

- economic responsibility concerning the costs of energy production, energy transmission, and the reliability of the energy supply to all sectors of the economy. 
For these reasons, the energy sector is of strategic importance for the sustainable development of not only national economies but also in the international context. In this regard, we share the authors' view $[11,12,83]$ that energy companies are particularly obliged to conduct CSR activities and implement sustainable development principles.

\subsection{Factors Motivating Energy Companies to Engage in CSR Activities}

In general, companies engage in CSR voluntarily, driven by ethical and altruistic motives, or are expecting various benefits (financial, reputational, and image-related) or are under the pressure of social expectations and pressures from different stakeholder groups $[16,17]$. Energy companies undertake CSR activities mainly for the following reasons:

- $\quad$ increasing competition in the industry, related to the use of renewable energy sources;

- the increasing number of national and international regulations introduced due to climate change $\left(\mathrm{CO}_{2}\right.$ emission limits); and

- the pressure of different stakeholder groups and the need to obtain a kind of social license to operate [52].

Considering the importance of the energy industry for the implementation of the assumptions of sustainable development not only on a national scale but also on a global scale, we believe that energy companies should formulate and implement CSR strategies that are embedded in their business strategies as suggested by many authors [53-55]. This is because such an approach offers the potential to obtain long-term benefits such as building a strong and positive reputation that in the long run will translate into better financial results and gain long-term competitive advantages.

\subsection{The Problem of Assessing and Measuring Companies' Involvement in CSR Activities on the} Basis of Publicly Available Information Published in Periodic Reports

The main problems hindering the assessment of the engagement in CSR activities stem from two main reasons:

- $\quad$ the lack of a universal CSR reporting obligation and

- the lack of uniform rules regarding the manner and scope of reporting [58,71].

It is worth mentioning here Dong and Xu's [50] study on the CSR engagement and reporting of 60 mining companies listed on the Shanghai and Shenzhen stock exchanges in 2007-2012. The results showed that, forced by regulations, companies prepared CSR reports but their content and quality left much to be desired. However, it should be noted that although regulations are necessary, mandatory CSR reporting requirements may result in a passive acceptance of regulations without a real change in corporate responsibility and improved transparency.

A solution to this problem could be the introduction of standardised CSR reporting standards at the international level as suggested by some authors [72,73]. Such standards should consider not only descriptive but, above all, quantitative information that will facilitate the objective comparison of various entities in terms of their involvement in CSR activities and enable assessment of the effectiveness of these activities. Currently published CSR reports, at least in Polish conditions, focus mainly on descriptive information which in the context of a comparative analysis of enterprises is actually incomparable and thus to a large extent useless (rather than a hundred-page descriptive report, one page of standardised quantitative data on relations with particular stakeholders of the enterprise would offer more from the scientific perspective).

\subsection{Assessment of the Involvement of Polish Energy Companies in CSR Activities}

The assessment of the involvement of Polish energy companies in CSR activities was established using a procedure based on the methods of multidimensional comparative analysis. The calculations used data from the consolidated annual reports of the companies for the years 2016-2020. The obtained results determined it possible to assess both the overall CSR commitment of the companies and the commitment in relation to: contractors, donors of capital, employees, society, and the environment. At the end of 2020, almost all 
the investigated energy companies demonstrated a similar overall level of CSR engagement, falling within the range of 0.5-0.6. However, during the studied period, the trends of the overall assessment varied: one company (Polenergia) showed an upward trend, one company (Energa) showed relative stability, and the remaining companies were characterized by a downward trend. Synthetic partial evaluations in the examined thematic areas revealed to be very diverse. The lowest scores (0.3-0.4) in the case of almost all companies concerned donors of capital and the natural environment, while the highest scores (0.7-0.8) were given to contractors and employees. In the area of society, ratings varied considerably (from 0.3 to 0.7 ).

In the context of the applied assessment model of the involvement of energy companies in socially responsible activities, it is worth noting two issues that are often raised in the literature in relation to models based on the financial data of enterprises; i.e., related to endogeneity problem and size of the company. Although the problem of endogeneity is most often raised in relation to regression models, it is worth considering in general in relation to research based upon the financial data of enterprises. The problem of endogeneity shows that explanatory variables not only affect the explained variable but are also often correlated with the random component of the model. This component is usually identified with other explanatory variables not included in the model, most often related to soft, non-measurable aspects of enterprise activity (e.g., managerial competence) [84-86]. In turn, in the case of company size, the significance of this characteristic is indicated in the context of the often occurring positive or negative correlation with various indicators used in corporate finance [87]. In the applied model, the influence of this characteristic was omitted due to the fact that all the studied capital groups belonged to one group of large entities according to EU requirements. However, considering that there were obviously smaller or larger differences between them in terms of basic variables describing the size of the company (employment, total assets, equity, revenue, and market capitalization), in further studies this aspect will be further analysed.

The obtained results, due to the applied assessment method, are difficult to relate to the results of other studies on the involvement of Polish enterprises in CSR, including energy companies which are mainly the result of surveys [88]. Cyclical publications include in particular: the ESG Index (which replaced the Respect Index) published by WSE [89,90] and the Ranking of Responsible Companies organised by Koźmiński Business Hub [91]. In both cases, however, detailed results of the assessments are not disclosed which presents difficulties when comparing the indications of these approaches with the results obtained in the presented research. It can only be noted that in both approaches from the energy sector, companies mentioned include: Enea, Energa, PGE, and Tauron.

Due to the significant impact of the energy sector on the state of the environment and climate change, the environmental CSR activities of energy companies are of particular importance in the pursuit of sustainable development [92]. In particular, it is about reducing the use of carbon-intensive energy sources and switching to renewable energy sources. Research has shown that Polish energy companies are very poorly involved in the implementation of low-carbon energy sources (environmental indicators at 0.2-0.3, Figure 6). Only two companies, Polenergia and Energa, are more advanced in producing energy from renewable sources. The Polish energy sector is based mainly on traditional resources such as hard coal and lignite. According to February 2021 data from the Polish Energy Market Agency, the Polish energy mix consists of 70\% hard coal (46\%) and lignite (24\%). Renewable sources such as wind, biomass, water, and sun constitute only about $18 \%$ of the energy mix [93].

Poland, like other EU countries, faces the challenge of energy transformation that assumes decarbonisation and achieving climate neutrality by 2050, in accordance with the assumptions of the Green Deal [94]. For power companies, this means shifting to renewable, low-carbon energy production [95]. These ambitious plans collide with political and social problems within the EU. The member states differ in their socio-economic structure and energy mix, indicating that the governments of individual countries often have divergent 
interests [96]. Germany and Scandinavian countries are the leaders in the implementation of the European climate policy, while countries of Central and Eastern Europe, including Poland, are the least advanced in this respect $[97,98]$.

It should be noted that the European energy transformation also has political consequences as it may affect external relations with suppliers of traditional raw materials (e.g., gas from Russia). In particular, it concerns the process of converting natural gas into hydrogen and the problem of storing/using produced $\mathrm{CO}_{2}[96,99]$. Burke and Stephens [100] believe that more diffused energy sources (renewable energy systems) offer opportunities for a more democratic energy future.

\section{Conclusions and Policy Implications}

In recent years, the concept of CSR has been gaining an ever-widening context and significance as it has been incorporated into the concept of sustainable development. According to the assumptions of sustainable development, enterprises of all branches should independently and voluntarily undertake CSR activities and/or actively participate in pro-social and environmental initiatives in order to inhibit and susceptibly limit the adverse impact of business on the natural environment and well-being of entire societies. Companies from the energy sector, due to the strategic and political importance of this sector and its huge impact on the state of the environment (climate change and $\mathrm{CO}_{2}$ emissions), are particularly predisposed and obliged to broadly engage in CSR and actively join the implementation of the sustainable development principles.

In this context, significant policy implications of the conducted research can be indicated. The results obtained may be useful for state authorities (the government) as information/guidance and inspiration to introduce relevant regulations and instruments stimulating the implementation of CSR by energy companies. The proposed assessment methodology makes it possible to assess not only the general involvement of companies in socially responsible activities but also the involvement in various thematic areas. The involvement of energy companies in the area of natural environment, in the context of sustainable development and climate protection, is particularly important. It means striving for diversification of energy sources with the use of renewable sources. The present study shows that the level of involvement of Polish energy companies in the area of the natural environment is relatively low. The applied assessment method allows also to identify stimulants for CSR activities in particular areas (assessment criteria presented in Tables 1 and 2), which is valuable information from the perspective of shaping government policy selection of appropriate instruments of influence.

The research results can also be used by the management boards of energy companies as a source of important decision-making information. Due to information on the level of involvement in CSR in the five dimensions including activities towards contractors (customers and suppliers), investors/creditors, employees, society, and the natural environment, energy companies can more precisely and multidimensionally assess their involvement in CSR and identify their weak points in comparison with competitors. Analyses conducted on this basis can help managers plan better, more effective CSR strategies.

CSR is currently a very important instrument for building a positive reputation of a company. Many stakeholder groups evaluate a company through the prism of its social involvement; these are environmentally conscious and sensitive consumers, environmentally conscious employees, suppliers and co-operators operating in sustainable supply chains, social institutions, and pro-ecological organisations. Research results providing information regarding the social commitment of investigated energy companies can be for such groups of stakeholders a criterion for the selection of an energy supplier, business partner, employer, or motivation to make other decisions supporting (directly or indirectly) the activities of the energy company.

The present research used data from annual reports of energy companies. Attention has been paid to the problems of CSR reporting raised by many authors: lack of obligation to publish CSR reports and varied scope and manner of reporting. The suggestions 
contained in the article may provide impetus and guidance to relevant international or national institutions regarding the introduction of an obligation and uniform principles of CSR reporting (standardization) for enterprises.

The research presented in this article is a methodological and analytical addition to the knowledge present for the assessment of enterprises' involvement in CSR. The proposed model of assessing the involvement of energy enterprises in socially responsible activities coincides with the dynamic development in recent years of methodologies for measuring enterprises' CSR activities. Unlike the dominant approaches based on surveys or qualitative criteria, the model used is based only on quantitative variables obtained from periodic (especially annual) reports of enterprises. Despite some limitations in terms of information, this approach has made it possible to select a number of indicators referring to the activity of enterprises in relation to five main groups of stakeholders: business partners, capital providers, employees, society, and the environment. This approach is therefore more comprehensive. An additional advantage of the proposed solution is the ease of access to data, their regular updating, and relative objectivity (quantitative data, especially financial, reported by companies are the result of applying generally accepted principles, e.g., IAS/IFRS).

Like any model, the proposed one also has some limitations. Firstly, it is dedicated to the assessment of CSR engagement in energy companies due to the application of specific assessment criteria in the area of natural environment. In the case of assessing companies with a different profile of activity, the criteria in the environmental area would have to be appropriately modified. Secondly, this model is strongly dependent on the availability and reliability of quantitative data published by enterprises which generally varies. Thirdly, a significant limitation is also the lack of consideration provided to company size characteristics that in corporate finance research is often an important factor differentiating the interpretation of particular variables and influencing the final assessment.

Nonetheless, the research results obtained through the applied method can be an inspiration and starting point for further research in the field of CSR. Firstly, they can be used as a comparative basis for the assessment of changes in the level of involvement of Polish energy companies in CSR activities in subsequent years. Secondly, they can be used to conduct comparative analysis at the level of the industry and individual energy companies from other countries. Thirdly, they can be used to measure the relationship between the level of enterprise involvement in CSR and its financial or market results.

Author Contributions: Conceptualization, T.L.N. and D.S.; methodology, T.L.N. and D.S.; software, T.L.N. and D.S.; validation, T.L.N. and D.S.; formal analysis, T.L.N. and D.S.; investigation, T.L.N. and D.S.; resources, T.L.N. and D.S.; data curation, T.L.N. and D.S.; writing-original draft preparation, T.L.N. and D.S.; writing-review and editing, T.L.N. and D.S.; visualization, T.L.N. and D.S.; supervision, T.L.N. and D.S.; project administration, T.L.N. and D.S.; funding acquisition, T.L.N. and D.S. (Silesian University of Technology). Both authors have read and agreed to the published version of the manuscript.

Funding: This study was funded by the Faculty of Organization and Management at Silesian University of Technology, grant number 13/010/BK_21/0057.

Institutional Review Board Statement: Not applicable.

Informed Consent Statement: Not applicable.

Data Availability Statement: The data for the study was derived from the annual reports of the analysed energy companies, available on their corporate websites in the investor relations section: https://ir.enea.pl/, accessed on 30 April 2021, https://ir.energa.pl/, accessed on 30 April 2021, https:/ / polenergia.pl/pol/en/shareholders, accessed on 30 April 2021, https:/ /www.gkpge.pl/ investor-relations, accessed on 30 April 2021, https: / / en.tauron.pl/investor-relations, accessed on 30 April 2021, and https:/ / ri.zepak.com.pl/en/, accessed on 30 April 2021.

Conflicts of Interest: The authors declare no conflict of interest. 


\section{References}

1. Wang, H.; Tong, L.; Takeuchi, R.; George, G. Corporate Social Responsibility: An overview and new research directions thematic issue on Corporate Social Responsibility. Acad. Manag. J. 2016, 59, 534-544. [CrossRef]

2. Valente, M. Business sustainability embeddedness as a strategic imperative: A process framework. Bus. Soc. 2015, 54, 126-142. [CrossRef]

3. Idowu, S.-O.; Dragu, I.-M.; Tiron-Tudor, A.; Farcas, T.-V. From CSR and sustainability to integrated reporting. Int. J. Soc. Entrep. Innov. 2016, 4, 134-151. [CrossRef]

4. Kolk, A. The social responsibility of international business: From ethics and the environment to CSR and sustainable development. J. World Bus. 2016, 51, 23-34. [CrossRef]

5. Zhang, D.; Morse, S.; Kambhampati, U. Sustainable Development and Corporate Social Responsibility; Routledge: New York, NY, USA, 2017; pp. 46-94.

6. Jain, R.; Winner, L.H. CSR and sustainability reporting practices of top companies in India. Corp. Commun. Int. J. 2016, 21, 36-55. [CrossRef]

7. Our Common Future: Report of the World Commission on Environment and Development. Available online: http:/ /www.undocuments.net/ocf-02.htm (accessed on 7 April 2021).

8. De Jong, M.D.T.; van der Meer, M. How Does It Fit? Exploring the Congruence Between Organizations and Their Corporate Social Responsibility (CSR) Activities. J. Bus. Ethics 2015, 143, 71-83. [CrossRef]

9. Zieliński, M.; Jonek-Kowalska, I. Profitability of Corporate Social Responsibility Activities from the Perspective of Corporate Social Managers. Eur. Res. Stud. J. 2020, 13, 264-280. [CrossRef]

10. Yang, S.; Chen, W.; Kim, H. Building Energy Commons: Three Mini-PV Installation Cases in Apartment Complexes in Seoul. Energies 2021, 14, 249. [CrossRef]

11. Stjepcevic, J.; Siksnelyte, I. Corporate Social Responsibility in Energy Sector. Transform. Bus. Econ. 2017, 16, 21-33.

12. Lu, L.; Ren, L.; Qiao, J.; Yao, S.; Strielkowski, W.; Streimikis, J. Corporate Social Responsibility and Corruption: Implications for the Sustainable Energy Sector. Sustainability 2019, 11, 4128. [CrossRef]

13. Clift, R. Climate change and energy policy: The importance of sustainability arguments. Energy 2007, 32, 262-268. [CrossRef]

14. Jonek-Kowalska, I. How do turbulent sectoral conditions sector influence the value of coal mining enterprises? Perspectives from the Central-Eastern Europe coal mining industry. Resour. Policy 2018, 55, 103-112. [CrossRef]

15. García- Rodríguez, F.; García- Rodríguez, J.; Castilla- Gutiérrez, C.; Major, S. Corporate social responsibility of oil companies in developing countries: From altruism to business strategy. Corp. Soc. Responsib. Environ. Manag. 2013, 20, 371-384. [CrossRef]

16. Groza, M.D.; Pronschinske, M.R.; Walker, M. Perceived organizational motives and consumer responses to proactive and reactive CSR. J. Bus. Ethics 2011, 102, 639-652. [CrossRef]

17. Garay, L.; Font, X. Doing good to do well? Corporate social responsibility reasons, practices and impacts in small and medium accommodation enterprises. Int. J. Hosp. Manag. 2012, 31, 329-337. [CrossRef]

18. Morsing, M.; Schultz, M. Corporate social responsibility communication: Stakeholder information, response and involvement strategies. Bus. Ethics A Eur. Rev. 2006, 15, 323-338. [CrossRef]

19. Becker-Olsen, K.L.; Cudmore, B.A.; Hill, R.P. The impact of perceived corporate social responsibility on consumer behavior. J. Bus. Res. 2006, 59, 46-53. [CrossRef]

20. Izzo, M.F.; di Donato, F. The Relation between Corporate Social Responsibility and Stock Prices: An Analysis of the Italian Listed Companies. Available online: http:/ / ssrn.com/abstract=1986324 (accessed on 4 May 2021). [CrossRef]

21. Tang, Z.; Eiríkur Hull, C.; Rothenber, S. How Corporate Social Responsibility Engagement Strategy Moderates the CSR-Financial Performance Relationship. J. Manag. Stud. 2012, 49, 1274-1303. [CrossRef]

22. Serveas, H.; Tamayo, A. The Impact of Corporate Social Responsibility on Firm Value: The Role of Customer Awareness. Manag. Sci. 2013, 59, 1045-1061. [CrossRef]

23. Cheng, B.; Ioannou, I.; Serafeim, G. Corporate Social Responsibility and Access to Finance. Strateg. Manag. J. 2014, 35, 1-23. [CrossRef]

24. Flammer, C. Does corporate social responsibility lead to superior financial performance? A regression discontinuity approach. Manag. Sci. 2015, 61, 2549-2568. [CrossRef]

25. Malik, M. Value-enhancing capabilities of CSR: A brief review of contemporary literature. J. Bus. Ethics 2015, 127, 419-438. [CrossRef]

26. Zhao, X.; Murrell, A.J. Revisiting the corporate social performance-financial performance link: A replication of Waddock and Graves. Strateg. Manag. J. 2016, 37, 2378-2388. [CrossRef]

27. Mattingly, J.E. Corporate social performance: A review of empirical research examining the corporation-society relationship using Kinder, Lydenberg, Domini social ratings data. Bus. Soc. 2017, 56, 796-839. [CrossRef]

28. Shahzad, A.M.; Sharfman, M.P. Corporate social performance and financial performance sample-selection issues. Bus. Soc. 2017, 56, 889-918. [CrossRef]

29. Pätäri, S.; Arminen, H.; Tuppura, A.; Jantunen, A. Competitive and responsible? The relationship between corporate social and financial performance in the energy sector. Renew. Sustain. Energy Rev. 2014, 37, 142-154. [CrossRef]

30. Shahbazab, M.; Karaman, A.-S.; Kilic, M.; Uyar, A. Board attributes, CSR engagement, and corporate performance: What is the nexus in the energy sector? Energy Policy 2020, 143, 111582, 1-4. [CrossRef] 
31. Haigh, M.M.; Dardis, F. The impact of apology on organization-Public relationships and perceptions of corporate social responsibility. Public Relat. J. 2012, 6, 1-16.

32. Fatma, M.; Rahman, Z.; Khan, I. Building company reputation and brand equity through CSR: The mediating role of trust. Int. J. Bank Mark. 2015, 33, 840-856. [CrossRef]

33. Cheng, S.; Lin, K.Z.; Wong, W. Corporate Social Responsibility Reporting and Firm Performance: Evidence from China. J. Manag. Gov. 2016, 20, 503-523. [CrossRef]

34. Aksak, E.O.; Ferguson, M.A.; Dumari, S.A. Corporate social responsibility and CSR fit as predictors of corporate reputation: A global perspective. Public Relat. Rev. 2016, 42, 79-81. [CrossRef]

35. Cowan, K.; Guzman, F. How CSR reputation, sustainability signals, and country-of-origin sustainability reputation contribute to corporate brand performance: An exploratory study. J. Bus. Res. 2020, 117, 683-693. [CrossRef]

36. Sparkes, R.; Cowton, C.J. The maturing of socially responsible investment: A review of the developing link with corporate social responsibility. J. Bus. Ethics 2004, 52, 45-57. [CrossRef]

37. El Ghoul, S.; Guedhami, O.; Kwok, C.C.Y.; Mishra, D.R. Does corporate social responsibility affect the cost of capital? J. Bank. Financ. 2011, 35, 2388-2406. [CrossRef]

38. Jonek-Kowalska, I. Efficiency of Enterprise Risk Management (ERM) systems. Comparative analysis in the fuel sector and energy sector on the basis of Central-European companies listed on the Warsaw Stock Exchange. Resour. Policy 2019, 62, 405-415. [CrossRef]

39. Choi, B.; La, S. The impact of corporate social responsibility (CSR) and customer trust on the restoration of loyalty after service failure and recovery. J. Serv. Mark. 2013, 27, 223-233. [CrossRef]

40. Kim, S. What's worse in times of product-harm crisis? Negative corporate ability or negative CSR reputation? J. Bus. Ethics 2014, 123, 157-170. [CrossRef]

41. Lin, C.-P.; Chen, S.-C.; Chiu, C.-K.; Lee, W.-Y. Understanding purchase intention during product-harm crises: Moderating effects of perceived corporate ability and corporate social responsibility. J. Bus. Ethics 2011, 102, 455-471. [CrossRef]

42. Sprinkle, G.B.; Maines, L.A. The benefits and costs of corporate social responsibility. Bus. Horiz. 2010, 53, 445-453. [CrossRef]

43. Kim, S.-Y.; Park, H. Corporate social responsibility as an organizational attractiveness for prospective public relations practitioners. J. Bus. Ethics 2011, 103, 639-653. [CrossRef]

44. Glavas, A.; Kelley, K. The effects of perceived Corporate Social Responsibility on employee attitudes. Bus. Ethics Q. 2014, 24, 165-202. [CrossRef]

45. Jamali, D. A stakeholder approach to corporate social responsibility: A fresh perspective into theory and practice. J. Bus. Ethics 2008, 82, 213-231. [CrossRef]

46. Yusoff, H.; Mohamad, S.S.; Darus, F. The influence of CSR disclosure structure on corporate financial performance: Evidence from stakeholders' perspectives. Procedia Econ. Financ. 2013, 7, 213-220. [CrossRef]

47. Zhang, A.; Moffat, K.; Lacey, J.; Wang, J.; Gonzalez, R.; Uribe, K.; Cui, L.; Dai, Y. Understanding the social license to operate of mining at the national scale: A comparative study of Australia, China and Chile. J. Clean Prod. 2015, 108, 1063-1072. [CrossRef]

48. Lacey, J.; Lamont, J. Using social contract to inform social license to operate: An application in the Australian coal seam gas industry. J. Clean. Prod. 2014, 84, 831-839. [CrossRef]

49. Liu, S.; Kasturiratne, D.; Moizer, J. A hub-and-spoke model for multi-dimensional integration of green marketing and sustainable supply chain management. Ind. Mark. Manag. 2012, 41, 581-588. [CrossRef]

50. Dong, S.; $\mathrm{Xu}, \mathrm{L}$. The impact of explicit CSR regulation: Evidence from China's mining firms. J. Appl. Account. Res. 2016, 17, 237-258. [CrossRef]

51. Streimikiene, D.; Simanaviciene, Z.; Kovaliov, R. Corporate social responsibility for implementation of sustainable energy development in Baltic States. Renew. Sustain. Energy Rev. 2009, 13, 813-824. [CrossRef]

52. Latapí Agudelo, M.-A.; Johannsdottir, L.; Davidsdottir, B. Drivers that motivate energy companies to be responsible. A systematic literature review of Corporate Social Responsibility in the energy sector. J. Clean. Prod. 2020, 274, 119094. [CrossRef]

53. Porter, M.E.; Kramer, M.R. Strategy and society: The link between competitive advantage and corporate social responsibility. Harv. Bus. Rev. 2006, 84, 78-92.

54. Michel, N.; Buler, S. Maximizing the benefits of corporate social responsibility. How companies can derive benefits from corporate social responsibility. Eur. Sci. J. 2016, 1, 499-506.

55. Lunenberg, K.; Gosselt, J.-F.; De Jong, M.-D.-T. Framing CSR fit: How corporate social responsibility activities are covered by news media. Public Relat. Rev. 2016, 42, 943-951. [CrossRef]

56. Pfau, M.; Haigh, M.M.; Sims, J.; Wigley, S. The influence of corporate social responsibility campaigns on public opinion. Corp. Reput. Rev. 2008, 11, 145-154. [CrossRef]

57. Frost, G.; Jones, S.; Lee, P. The Measurement and Reporting of Sustainability Information within the Organization: A Case Analysis. In Contemporary Issues in Sustainability Accounting, Assurance and Reporting; Jones, S., Ratnatunga, J., Eds.; Emerald Publishing: Bingley, UK, 2012; pp. 197-225.

58. Szwajca, D.; Nawrocki, T.L. Możliwości oceny zaangażowania przedsiębiorstw w działania społecznie odpowiedzialne a ich polityka informacyjna w zakresie CSR. Przeglad Organizacji 2016, 4, 44-52. [CrossRef]

59. Peloza, J. The challenge of measuring financial impacts from investments in corporate social performance. J. Manag. 2009, 35, 1518-1541. [CrossRef] 
60. Nowak, A. Problemy pomiaru społecznej odpowiedzialności przedsiębiorstwa. Pr. Nauk. Uniw. Ekon. We Wrocławiu 2014, 329, 232-240.

61. Carroll, A.B. A commentary and an overview of key questions on corporate social performance measurement. Bus. Soc. 2000, 39, 466-478. [CrossRef]

62. Hopkins, M. Measurement of social corporate responsibility. Int. J. Manag. Decis. Mak. 2005, 6, 213-231. [CrossRef]

63. Marquez, A.; Fombrun, C.J. Measuring corporate social responsibility. Corp. Reput. Rev. 2005, 7, 304-308. [CrossRef]

64. Fombrun, C.J. List of lists: A Compilation of International Corporate Reputation Ratings. Corp. Reput. Rev. 2007, 10, 144-153. [CrossRef]

65. Turker, D. Measuring corporate social responsibility: A scale development study. J. Bus. Ethics 2009, 85, 411-427. [CrossRef]

66. Wood, D.J. Measuring corporate social performance: A review. Int. J. Manag. Rev. 2010, 12, 50-84. [CrossRef]

67. Maignan, I.; Ferrell, O.C. Measuring Corporate Citizenship in Two Countries: The Case of the United States and France. J. Bus. Ethics 2000, 23, 283-297. [CrossRef]

68. Crane, A.; Henriques, I.; Husted, B.-W.; Matten, D. Measuring Corporate Social Responsibility and Impact: Enhancing Quantitative Research Design and Methods in Business and Society Research. Bus. Soc. 2017, 56, 787-795. [CrossRef]

69. Ehsan, S.; Nazir, M.-S.; Nurunnabi, M.; Khan, O.-R.; Tahir, S.; Ahmed, I. A Multimethod Approach to Assess and Measure Corporate Social Responsibility Disclosure and Practices in a Developing Economy. Sustainability 2018, 10, 2995. [CrossRef]

70. Capelle-Blancard, G.; Petit, A. The weighting of CSR dimensions: One size does not fit all. Bus. Soc. 2017, 56, 919-943. [CrossRef]

71. Lulewicz-Sas, A. Społeczna odpowiedzialność biznesu w wybranych krajach Unii Europejskiej. Ekon. i Prawo 2013, 12, 537-550. [CrossRef]

72. Tschopp, D.; Nastanski, M. The Harmonization and Convergence of Corporate Social Responsibility Reporting Standards. J. Bus. Ethics 2014, 125, 147-162. [CrossRef]

73. Szczepankiewicz, E.I.; Mućko, P. CSR Reporting Practices of Polish Energy and Mining Companies. Sustainability 2016, 8, 126. [CrossRef]

74. Sen, S.; Bhattacharya, C.B.; Korschun, D. The role of corporate social responsibility in strengthening multiple stakeholder relationships: A field experiment. J. Acad. Mark. Sci. 2006, 34, 158-166. [CrossRef]

75. Hermann, S.P. Stakeholder Based Measuring and Management of CSR and Its Impact on Corporate Reputation. In From Customer Retention to a Holistic Stakeholder Management System; Huber, M., O’Girman, S., Eds.; Springer-Verlag: Berlin/Heidelberg, Germany, 2008; pp. 51-61.

76. Papania, L.; Shapiro, D.M.; Peloza, J. Social Impactas a Measure of Fit betweet Firm Activitiesand Stakeholder Expectations. Int. J. Bus. Gov. Ethics 2008, 4, 3-16. [CrossRef]

77. Lex, A.; Streit, M.; Partl, C.; Kashofer, K.; Schmalsteig, D. Comparative Analysis of Multidimensional, Quantitative Data. IEEE Trans. Vis. Comput. Graph. 2010, 16, 1027-1035. [CrossRef] [PubMed]

78. Panek, T.; Zwierzchowski, J. Statystyczne Metody Wielowymiarowej Analizy Porównawczej; Oficyna wydawnicza SGH: Warsaw, Poland, 2013.

79. Dmitruk, J.; Gawinecki, J. Metody Wielowymiarowej Analizy Porównawczej-Budowa i Zastosowanie. Biuletyn WAT 2017, 66, 103-119.

80. Walesiak, M. Podstawowe Zagadnienia Statystycznej Analizy Wielowymiarowej. In Metody Statystycznej Analizy Wielowymiarowej w Badaniach Marketingowych; Gatnar, E., Walesiak, M., Eds.; Wydaw. AE we Wrocławiu: Wrocław, Poland, $2004 ;$ pp. 17-59.

81. Strahl, D. Propozycja konstrukcji miary syntetycznej. Przeglad Stat. 1978, 25, 205-215.

82. Rozporzadzenie Komisji (UE) nr 651/2014 z Dnia 17 Czerwca 2014 r. (Dz. Urz. UE L 187 z dnia 26.06.2014 r.). Available online: https:/ / eur-lex.europa.eu/legal-content/PL/TXT/PDF/?uri=CELEX:32014R0651 (accessed on 18 July 2021).

83. Sugino, T.; Mayrowani, H.; Kobayashi, H. Determinants for CSR in Developing Countries: The Case of Indonesian Palm Oil Companies. Jpn. J. Rural Econ. 2015, 17, 18-34. [CrossRef]

84. Li, Z.F. Endogeneity in CEO power: A survey and experiment. Invest. Anal. J. 2016, 45, 149-162. [CrossRef]

85. Coles, J.L.; Li, Z.F. Managerial Attributes, Incentives, and Performance. Rev. Corp. Financ. Stud. 2020, 9, 256-301. [CrossRef]

86. Coles, J.L.; Li, Z.F. An Empirical Assessment of Empirical Corporate Finance. Available online: https://ssrn.com/abstract=1787 143 (accessed on 12 July 2021).

87. Dang, C.; Li, Z.F.; Yang, C. Measuring Firm Size in Empirical Corporate Finance. J. Bank. Financ. 2018, 86, 159-176. [CrossRef]

88. Wolska, G. Zaangażowanie przedsiębiorstw w realizację koncepcji społecznej odpowiedzialności na podstawie badań empirycznych przeprowadzonych w Polsce. Studia Ekonomiczne. Zesz. Nauk. Uniw. Ekon. Katowicach 2015, $236,85-95$.

89. GPW Uruchamia Indeks WIG-ESG. Available online: https://www.gpw.pl/aktualnosc?cmn_id=108700\&title=GPW+uruchamia+ indeks+WIG-ESG (accessed on 25 May 2021).

90. Index Factsheet: WIG-ESG. Available online: https:/ / gpwbenchmark.pl/karta-indeksu?isin=PL9999998955 (accessed on 25 May 2021).

91. Ranking Odpowiedzialnych Firm. Available online: http://rankingodpowiedzialnychfirm.pl/ (accessed on 25 May 2021).

92. Climate Change: Implications for the Energy Sector. Key Findings from the Intergovernmental Panel on Climate Change Fifth Assessment Report. University of Cambridge, World Energy Council, June 2014. Available online: https:/ / www.worldenergy.org/assets/images/imported/2014/06/Climate-Change-Implications-for-the-Energy-SectorSummary-from-IPCC-AR5-2014-Full-report.pdf (accessed on 16 July 2021). 
93. Źródła Energii w Polsce w 2020 Roku: Mniej Węgla, Więcej Gazu i OZE. Available online: https://wysokienapiecie.pl/35619zrodla-energii-w-polsce-w-2020-mniej-wegla-wiecej-gazu-oze (accessed on 14 July 2021).

94. Sustainable Europe investment Plan: European Green Deal Investment Plan. COM (2020) 21 Final. Brussels: European Commission. Available online: https:/ / eur-lex.europa.eu/legal-content/EN/TXT/?uri=CELEX\%3A52020DC0021 (accessed on 16 July 2021).

95. Makarov, A.A.; Mitrova, T.A.; Kulagin, V.A. Long-term development of the global energy sector under the influence of energy policies and technological progres. Russ. J. Econ. 2020, 6, 347-357. [CrossRef]

96. Hafner, M.; Raimondi, P.P. Priorities and challenges of the EU energy transition: From the European Green Package to the new Green Deal. Russ. J. Econ. 2020, 6, 374-389. [CrossRef]

97. EEA. Trends and Projections in Europe 2019: Tracking Progress Towards Europe's Climate and Energy Targets, EEA Report 15/2019; European Environment Agency: Luxembourg, 2019. [CrossRef]

98. Sweden Is a Leader in the Energy Transition, According to Latest IEA Country Review. Available online: https://www.iea.org/ news/sweden-is-a-leader-in-the-energy-transition-according-to-latest-iea-country-review (accessed on 12 July 2021).

99. Hatipoglu, E.; Muhanna, S.A.; Efird, B. Renewables and the future of geopolitics: Revisiting main concepts of international relations from the lens of renewables. Russ. J. Econ. 2020, 6, 358-373. [CrossRef]

100. Burke, M.J.; Stephens, J.C. Political power and renewable energy futures: A critical review. Energy Res. Soc. Sci. 2018, 35, 78-93. [CrossRef] 